\title{
PERAN KEPEMILIKAN TERHADAP KEBIJAKAN DIVIDEN
}

\author{
Novi S. Budiarso \\ (Email : novi_sbudiarso@yahoo.com)
}

\begin{abstract}
This study explores the role of ownership and the relationship to the separation and control issue. Investigate the nature of agency cost generated by the existence of the ownership. The principal purpose of this study was to investigate the association between the ownership and dividend policy. This empirical study using regression model for the hypothesis testing. The sample consists of 34 firms by 4 subsectors in period of 2010-2011, which is listed in Indonesia Stock Exchange.

The findings show that, partially, institutional ownership significantly influences dividend policy but the other side, public and managerial ownership not significantly influences to dividend policy. Simultaneously, institutional, public and managerial ownership influences dividend policy. The level and role of agency cost depends not only on ownership.

Keywords : kepemilikan institusi, kepemilikan publik, kepemilikan manajerial, kebijkan dividen
\end{abstract}

\section{PENDAHULUAN}

Mengapa perusahaan membayar dividen? Keputusan untuk laba ditahan atau membayar dividen untuk melindungi perusahaan dari masalah keagenan. Teori keagenan mengasumsikan bahwa laba bisa membuat manajer untuk melakukan tindakan yang tidak memaksimumkan kesejahteraan shareholder. Dividen, merupakan alat keuangan yang bernilai bagi perusahaan karena dapat membantu menghindari manajer dalam menggunakan aset untuk mengurangi investasi. Manajer membutuhkan kontrol atas sumber daya perusahaan baik dari kontribusi utang, modal maupun laba ditahan.

Mengapa kebijakan dividen penting? Beberapa penelitian menjelaskan hubungan antara manajemen laba dan kebijakan dividen perusahaan, penelitian yang lain mengangkat tentang kebijakan dividen dan harga saham serta stock returns. Hal penting lainnya adalah kebijakan dividen dengan konflik keagenan dimana kebijakan dividen bermanfaat untuk mengurangi konflik keagenan dan biaya keagenan.

Penelitian ini bertujuan untuk mengaplikasikan teori keagenan terhadap kebijakan dividen, dimana teori keagenan menyatakan bahwa pembayaran dividen merupakan salah satu alat ukur bagi manajer untuk mengontrol perilaku keagenan. Secara spesifik dengan cara mengurangi kontrol dari pihak eksternal, dividen mengurangi biaya keagenan, meskipun pada saat yang sama meningkatkan biaya transaksi sehubungan dengan meningkatnya pendanaan eksternal.

\section{TINJAUAN PUSTAKA}

Beberapa penelitian fokus terhadap hubungan keagenan dalam pembayaran dividen. Menurut teori keagenan, konflik agensi terjadi akibat adanya perbedaan kepentingan antara pemilik perusahaan dan para manajernya. Masalah konflik agensi dalam perusahaan biasanya terjadi karena pemilik perusahaan (principal) tidak dapat berperan aktif dalam manajemen perusahaan. Mereka mendelegasikan wewenang dan tanggung jawab pengelolaan perusahaan kepada para manajer profesional (agent) untuk bekerja atas nama dan untuk kepentingannya. Shleifer dan Vishny (1997) mengatakan bahwa esensi dari masalah keagenan adalah pemisahan atas manajemen dan keuangan atau kepemilikan dan kontrol. Manajer, mendapatkan dana dari 
investor dan menggunakannya untuk kegunaan yang produktif sebaliknya pemilik dana membutuhkan manajer sebagai modal untuk menghasilkan keuntungan dari dana yang diberikan. Manajer membutuhkan dana karena manajer tidak memiliki kecukupan modal untuk melakukan investasi. Tapi apakah pemilik dana yakin bahwa dana yang diberikan digunakan dengan semestinya? Masalah keagenenan dalam konteks ini merujuk pada kesulitan pemilik dana dalam hal keyakinan bahwa dana tersebut tidak digunakan untuk proyek yang tidak semestinya. Ide bahwa monitoring perusahaan dan manajemen dapat membantu mengurangi konflik keagenan Easterbrook (1984) menyarankan bahwa salah satu cara untuk mengatasi masalah ini adalah dengan meningkatkan pembayaran dividen.

Teori keagenan menurut Jensen dan Meckling (1976) menjelaskan tentang struktur modal perusahaan sebagai akibat dari minimisasi biaya-biaya sehubungan dengan pemisahan kontrol dan kepemilikan perusahaan. Biaya keagenan akan rendah pada perusahaan dengan kepemilikan manajerial yang tinggi karena mensejajarkan antara tujuan shareholder dan manager, disamping itu pada perusahaan dengan kepemilikan block shareholders yang besar lebih memungkinkan untuk memonitoring aktivitas manajer, Shleifer dan Vishny (1986). Rozeff (1982) pada penelitiannya menyatakan bahwa pembayaran dividen yang tinggi ditemukan pada perusahaanperusahaan dengan kepemilikan insider yang kecil dan kepemilikan outside shareholders yang besar. Hal ini merupakan implikasi bahwa kebijakan dividen akan mengurangi biaya agensi karena sebagian aktivitas monitoring dilakukan oleh pembayaran dividen. Dengan kata lain kebijakan dividen dan kepemilikan manajerial digunakan sebagai subtitusi untuk mengurangi biaya keagenan.

Modigliani dan Miller (1961) menyatakan bahwa pembayaran dividen tidak berpengaruh terhadap nilai perusahaan pada masa yang akan datang. Sehingga kebijakan dividen tidak relevan sebagi determinan dari nilai pasar, yang diberikan oleh kebijakan investasi. Jensen and Meckling (1976) mengatakan bahwa biaya monitoring dan utang atas manajer merupakan biaya keagenan yang dibuat oleh investor. Miller dan Rock (1985) mengembangkan teori signaling, menunjukkan bahwa informasi asimetri, menginformasikan pihak intern menggunakan kebijakan dividen sebagai biaya signal dalam upaya meningkatkan prospek perusahaan.

Shleifer dan Vishny (1986) menemukan kepemilikan institusional berpengaruh secara positif terhadap kepemilikan manajerial. Konsentrasi kepemilikan memberikan kondisi kepada pemegang saham mayoritas untuk memantau manajemen perusahaan Shleifer dan Vishny (1997) menyatakan bahwa pemegang saham mayoritas lebih memilih untuk mengambil keuntungan pribadi yang tidak dimiliki oleh pemegang saham publik. Keuntungan pribadi yang tidak dimiliki oleh pemegang saham publik adalah mengatur kebijakan perusahaan, menentukan keputusan strategis manajemen.

Rozeff (1982) dan Mohd, Perry, dan Rimbey (1995), menyatakan bahwa pembayaran dividen signifikan dengan peningkatan dari pemisahan kepemilikan, Hu dan Kumar (2004) menyatakan bahwa pembayaran dividen secara signifikan menurun dengan adanya shareholder yang besar. Mancinelli dan Ozkan (2006) menemukan bahwa terdapat hubungan negative signifikan antara pembayaran dividen dengan kekuasaan pengambilan keputusan oleh shareholder. Harada dan Nguyen (2011) menyatakan dalam hasil penelitian bahwa terdapat hubungan negative signifikan antara dividen dengan blockholder, khususnya sehubungan dengan kepemilikan institusional. 


\section{METODE PENELITIAN}

\subsection{Jenis dan Sumber Data}

Jenis data dalam penelitian ini adalah data kuantitatif yang berupa data rasio keuangan yang berasal dari laporan keuangan audit dan terpublikasi untuk periode tahun 2010 sampai dengan tahun 2011. Sedangkan sumber data dalam penelitian ini adalah berasal dari Bursa Efek Indonesia (BEI).

\subsection{Populasi dan Sampel}

Populasi dalam penelitian ini adalah seluruh perusahaan yang terdaftar dalam Bursa Efek Indonesia yang berjumlah 502 perusahaan. Sample penelitian dipilih menggunakan metode purposive sampling, diperoleh 34 perusahaan sebagai sample penelitian dengan 68 observasi (lihat Tabel 1).

Tabel 1. Sampel Penelitian

\begin{tabular}{lr}
\hline \multicolumn{1}{c}{ SEKTOR } & JUMLAH \\
\hline Agriculture & 8 \\
Mining & 9 \\
Miscellaneous Industry & 11 \\
Trade, Services \& Investment & 6 \\
\hline JUMLAH & $\mathbf{3 4}$ \\
\hline
\end{tabular}

\subsection{Metode Analisis}

Pengujian hipotesis dalam penelitian ini menggunakan analisis regresi berganda, dengan tingkat signifikansi $5 \%(\alpha=0.05)$. Persamaan yang digunakan adalah :

$$
\text { DPR }=\alpha+\text { BInst }+ \text { BMan }+ \text { BPublic }+ \text { BDER }+\varepsilon
$$

Untuk memperoleh model regresi berganda yang tidak bias, maka penelitian ini melakukan pengujian asumsi klasik sebagai berikut:

\section{Uji Normalitas}

Uji normalitas bertujuan untuk menguji variabel pengganggu atau residual memiliki distribusi normal. Uji yang dapat digunakan adalah uji statistik non parametrik Kolmogorov Smirnov (Ghozali, 2009).

\section{Uji Autokorelasi}

Uji autokorelasi bertujuan menguji apakah dalam model regresi linear ada korelasi antara kesalahan pengganggu pada periode $\mathrm{t}$ dengan kesalahan pengganggu pada periode $\mathrm{t}-1$ (Ghozali, 2009).

\section{Uji Multikolinearitas}

Variabel bebas yang saling berkorelasi akan menyebabkan variabel tersebut tidak orthogonal yaitu nilai korelasi antara sesama variabel bebas tidak sama dengan nol. Multikolinearitas dapat diketahui ada atau tidaknya dalam sebuah model. Dalam penelitian ini, uji multikolinearitas akan menggunakan nilai VIF dibawah 10 (Ghozali, 2009).

\section{Uji Heteroskedastisitas}

Uji Heteroskedastisitas bertujuan menguji apakah model regresi terjadi ketidaksamaan variance dari residual satu pengamatan ke pengamatan yang lain. Jika variance dari residual dari satu pengamatan ke pengamatan lain tetap disebut homoskedastisitas. Dalam penelitian ini, pengujian heteroskedastisitas akan menggunakan uji Glejser. Uji Glejser meregres nilai absolut residual terhadap variabel independen. Apabila nilai probabilitas koefisien regresi 
tersebut hasilnya signifikan di bawah tingkat signifikansi 0,05 , maka dapat dinyatakan terjadi heteroskedastisitas (Ghozali, 2009).

\subsection{Definisi Operasional dan Pengukuran Variabel}

Variabel independen dalam penelitian ini adalah kepemilikan institusional, kepemilikan manajerial dan kepemilikan publik. Sedangkan variabel dependen adalah kebijakan dividen. Pengukuran variabel independen dan dependen menggunakan proksi sebagai berikut :

1. Kepemilikan Institusional adalah pemegang saham berbentuk instansi/pemerintah yang tidak aktif dalam kegiatan operasional perusahaan. Kepemilikan institusional diformulasi sebagai berikut:

$$
\text { Kepemilikan institusional }=\frac{\text { Jumlah saham yang dimiliki institusional }}{\text { Jumlah saham beredar }} \times 100 \%
$$

2. Kepemilikan manajerial adalah kepemilikan saham oleh pihak manajemen dari dewan komisaris dan direksi yang turut mengambil keputusan kepemilikan manajerial. Kepemilikan manajerial diformulasi sebagai berikut:

$$
\text { Kepemilikan manajerial }=\frac{\text { Jumlah saham yang dimiliki insider }}{\text { Jumlah saham beredar }} \times 100 \%
$$

3. Kepemilikan public adalah kepemilikan saham oleh pihak public atau masyarakat. Kepemilikan public diformulasi sebagai berikut:

$$
\text { Kepemilikan public }=\frac{\text { Jumlah saham yang dimiliki public }}{\text { Jumlah saham beredar }} \times 100 \%
$$

4. Kebijakan Dividen

Kebijakan dividen merupakan salah satu kegiatan manajer keuangan untuk memutuskan mengenai pembagian dividen kepada para pemegang saham dari laba yang didapat oleh perusahaan ataukah akan ditahan dalam bentuk laba ditahan untuk membiayai investasi masa depan. Dividend payout ratio dapat dirumuskan dengan perbandingan dividen per share dengan earning per share dalam satuan persentase sebagai berikut:

$$
\text { Dividend Pay Out Ratio }=\frac{\text { Dividen Per Share }}{\text { Earnings Per Share }} \times 100 \%
$$

\subsection{Hipotesis}

$\mathrm{HO}_{1}$ : Kepemilikan institusional berpengaruh tidak signifikan pada kebijakan dividen di Bursa Efek Indonesia (BEI).

$\mathrm{Ha}_{1}$ : Kepemilikan institusional berpengaruh signifikan pada kebijakan dividen di Bursa Efek Indonesia (BEI).

$\mathrm{HO}_{2}$ : Kepemilikan manajerial berpengaruh tidak signifikan pada kebijakan dividen di Bursa Efek Indonesia (BEI). 
$\mathrm{Ha}_{2}$ : Kepemilikan manajerial berpengaruh signifikan pada kinerja perusahaan perdagangan, jasa dan investasi di BEI.

$\mathrm{HO}_{3}$ : Kepemilikan public berpengaruh tidak signifikan pada kebijakan dividen di Bursa Efek Indonesia (BEI).

$\mathrm{Ha}_{3}$ : Kepemilikan public berpengaruh signifikan pada kebijakan dividen di Bursa Efek Indonesia (BEI).

\section{HASIL PENELITIAN DAN PEMBAHASAN}

\subsection{Hasil Penelitian}

Hasil penelitian akan menguraikan hasil analisis atas uji asumsi klasik, persamaan regresi berganda, koefisien korelasi, koefisien determinasi dan uji simultan (uji F). Uraian atas hasil uji asumsi klasik dapat diuraikan sebagai berikut :

\section{Uji Normalitas}

Berdasarkan uji Kolmogorov Smirnov, ditemukan tingkat signifikansi $0.553>0.05$, sehingga dapat disimpulkan bahwa residual error data terdistribusi normal (lihat Tabel 2).

Tabel 2. Uji Normalitas - Kolmogorov Smirnov

\begin{tabular}{llr}
\hline & & Unstandardized Residual \\
\hline Normal Parameters & & 68 \\
& & Mean \\
Most Extreme Differences & Std. Deviation & 0.0000000 \\
& Absolute & 0.81308503 \\
& Positive & 0.096 \\
Kolmogorov-Smirnov Z & Negative & 0.092 \\
Asymp. Sig. (2-tailed) & & -0.096 \\
\hline a. Test distribution is Normal. & & 0.795 \\
b. Calculated from data. & & 0.553 \\
\hline
\end{tabular}

\section{Uji Autokorelasi}

Nilai Durbin Watson (lihat Tabel 3) yang diperoleh adalah 1.789, dapat disimpulkan tidak terjadi autokorelasi pada data penelitian ini.

Tabel 3. Uji Autokorelasi - Durbin Watson

Model

Durbin - Watson

a. Predictors: (Constant), Manajerial, Inst, Public

b. Dependent Variable: DPR

\section{Uji Multikolinearitas}

Hasil pengujian menunjukkan bahwa semua nilai Tolerance dan nilai VIF dari variabel independen memiliki nilai Tolerance $>0,10$ dan nilai VIF $<10$, maka dapat disimpulkan bahwa antar variabel independen tidak terjadi efek multikolinearitas (lihat Tabel 4). 
Tabel 4. Uji Multikolinearitas

\begin{tabular}{|c|c|c|c|}
\hline \multirow{2}{*}{\multicolumn{2}{|c|}{ Model }} & \multicolumn{2}{|c|}{ Collinearity Statistics } \\
\hline & & Tolerance & VIF \\
\hline \multirow[t]{4}{*}{1} & (Constant) & & \\
\hline & Inst. & 0.881 & 1.136 \\
\hline & Public & 0.795 & 1.258 \\
\hline & Manajerial & 0.897 & 1.115 \\
\hline
\end{tabular}

a. Dependent Variable: DPR

\section{Uji Heteroskedastisitas}

Hasil Uji Glesjer, ditemukan bahwa tingkat signifikansi setiap variabel independen terhadap logaritma natural residual error berada diatas 0.05 , sehingga disimpulkan bahwa varians data penelitian adalah homoskedastisitas.

\section{Uji Regresi Linear Berganda}

Berdasarkan hasil analisis regresi berganda, maka koefisien setiap variabel independen dalam penelitian ini adalah sebagai berikut (lihat Tabel 7) :

Tabel 7. Uji Regresi Berganda

\begin{tabular}{llrrrrr}
\hline & & \multicolumn{2}{c}{ Unstandardized } & \multicolumn{2}{c}{ Standardized } & \\
Coefficients & \multicolumn{2}{c}{ Coefficients } & & \\
\cline { 3 - 5 } Model & & \multicolumn{1}{c}{ B } & Std. Error & \multicolumn{1}{c}{ Beta } & \multicolumn{1}{c}{ Sig. } \\
\hline 1 & (Constant) & 4.071 & 0.230 & & 17.704 & 0.000 \\
& Inst & 1.091 & 0.360 & 0.373 & 3.028 & 0.004 \\
& Public & 0.043 & 0.124 & 0.045 & 0.345 & 0.731 \\
& Manajerial & -0.259 & 0.271 & -0.117 & -0.956 & 0.343 \\
\hline
\end{tabular}

${ }^{\mathrm{a}}$ Dependent Variable: DPR

Berdasarkan hasil analisis tersebut, maka persamaan regresi berganda dalam penelitian ini dapat dituliskan sebagai berikut :

$$
\text { DPR }=4.071+1.091 \text { Inst }+ \text { 0.043Public }-0.259 \text { Manajerial }+c
$$

\section{Koefisien Korelasi dan Determinasi}

Berdasarkan hasil analisis (lihat Tabel 5), nilai korelasi (R) adalah sebesar 0.382, yang berarti terdapat hubungan yang lemah antara variabel dependen dengan variabel independen. Sedangkan kontribusi variabel independen untuk menjelaskan model variabel dependen berdasarkan koefisien determinasi $\left(\mathrm{R}^{2}\right)$ adalah sebesar $14,6 \%$, sedangkan sisanya dijelaskan oleh variabel lain yang tidak dimasukkan dalam penelitian ini.

Tabel 5. Koefisien Korelasi dan Determinasi

\begin{tabular}{lccrr}
\hline Model & R & R Square & Adjusted R Square & Std. Error of the Estimate \\
\hline 1 & $0.382^{\text {a }}$ & 0.146 & 0.106 & 0.83192 \\
\hline $\begin{array}{l}\text { a. Predictors: (Constant), Manajerial), Inst, Public } \\
\text { b. Dependent Variable: DPR }\end{array}$
\end{tabular}




\section{Uji Signifikansi Simultan (uji F)}

Berdasarkan hasil analisis untuk uji simultan (lihat Tabel 6), ditemukan bahwa nilai $F$ adalah sebesar 3.638 yang signifikan pada taraf 5\%, sehingga dapat disimpulkan bahwa secara bersamasama, variabel kepemilikan institusional, kepemilikan publik dan kepemilikan manajerial signifikan berpengaruh terhadap kebijakan dividen.

Tabel 6. Uji F - ANOVA ${ }^{\mathrm{b}}$

\begin{tabular}{llrrrrr}
\hline Model & & Sum of Squares & df & Mean Square & F & Sig. \\
\hline 1 & Regression & 7.553 & 3 & 2.518 & 3.638 & $0.017^{\mathrm{a}}$ \\
& Residual & 44.294 & 64 & 0.692 & & \\
& Total & 51.847 & 67 & & & \\
\hline
\end{tabular}

a. Predictors: (Constant), Manajerial, Inst, Public

b. Dependent Variable: DPR

\subsection{Pembahasan}

Pembahasan untuk setiap pengujian hipotesis dalam penelitian ini akan mengacu pada hasil uji regresi berganda (lihat Tabel 7).

\section{Uji Hipotesis 1}

Hasil uji statistik (uji t) menunjukkan bahwa Ho ditolak, dimana kepemilikan institusional berpengaruh terhadap kebijakan dividen perusahaan di BEI, dengan tingkat signifikansi $0.004<$ 0.05. Hal ini berarti bahwa semakin tinggi kepemilikan institusional semakin tinggi pula tingkat pembayaran dividen. Hasil uji hipotesis ini mendukung penelitian Rozeff (1982) dan Mohd, Perry, dan Rimbey (1995), Hu dan Kumar (2004), Mancinelli dan Ozkan (2006), Harada dan Nguyen (2011) dan Khan (2006), yang menyatakan bahwa dividen merupakan salah satu alat untuk mekanisme kontrol atas manajer dan mekanisme dari signaling. Kepemilikan institusional pada perusahaan-perusahaan yang terdaftar pada BEI relatif kecil, masih di bawah optimal level dari monitoring yang dianggap seharusnya sebagai standar. Hal ini menyebabkan shareholders menuntut pembayaran dividen yang tinggi guna meningkatkan monitoring.

\section{Uji Hipotesis 2}

Hasil uji statistik (uji t) menunjukkan bahwa $\mathrm{H}_{0}$ diterima, dimana kepemilikan publik tidak berpengaruh terhadap kebijakan dividen perusahaan di BEI, dengan tingkat signifikansi 0.731>0.05. Hasil uji hipotesis ini mendukung penelitian Miller dan Modigliani (1961) yang menyatakan bahwa kepemilikan tidak berpengaruh signifikan terhadap kebijakan dividen. Hal ini disebabkan karena kepemilikan publik di Indonesia pada umumnya $<5 \%$, sehingga rata-rata kepemilikan individual sangat kecil.

\section{Uji Hipotesis 3}

Hasil uji statistik (uji t) menunjukkan bahwa $\mathrm{H}_{0}$ diterima, dimana kepemilikan manajerial tidak berpengaruh terhadap kebijakan dividen perusahaan di BEI, dengan tingkat signifikansi $0.343>0.05$. Hasil uji hipotesis ini mendukung penelitian Miller dan Modigliani (1961) yang menyatakan bahwa kepemilikan tidak berpengaruh terhadap kebijakan dividen. Kenaikan kepemilikan manajerial tidak menyebabkan konflik keagenan yang potensial.

\section{KESIMPULAN}

Kepemilikan dapat mewakili sumber kekuasaan yang dapat digunakan untuk mendukung atau sebaliknya terhadap keberadaan manajemen, maka penyebaran kepemilikan identik dengan 
penyebaran kekuasaan merupakan sesuatu hal yang relevan. Kepemilikan institusional memegang peranan yang signifikan terhadap kebijakan dividen pada perusahaan yang terdaftar pada perusahaan-perusahaan yang terdaftar di BEI, namun tidak sampai pada level monitoring yang optimal. Sedangkan kepemilikan public dan manajerial, hanya memiliki rasio pembayaran dividen (DPR) yang kecil sehingga hanya merupakan bagian kecil saja dari keputusan investasi perusahaan.

Kebijakan dividen hampir sepenuhnya ditentukan oleh kebijakan investasinya dan perlakuan laba menjadi dividen dan laba ditahan tidak mempengaruhi kebijakan dividen perusahaan. Kebijakan dividen pada perusahaan-perusahaan yang terdaftar di BEI lebih banyak dipengaruhi oleh faktor yang lain seperti struktur modal dan kebijakan utang sehingga menempatkan manajer di bawah pengawasan debtholder.

\section{SARAN}

Penelitian selanjutnya sebaiknya menggunakan sampel yang lebih besar, karena dengan penambahan sektor yang lain pada perusahaan yang terdaftar di BEI, maka akan meningkatkan validitas hasil penelitian tersebut. Kepemilikan institusional dalam penelitian ini tidak diklasifikasikan berdasarkan kepemilikan oleh pemerintah, bank ataupun asuransi. Penelitian selanjutnya diharapkan melakukan klasifikasi kepemilikan sehingga dispersi atas kepemilikan dapat terlihat jelas dan hasilnya dapat diperbandingkan.

Penelitian selanjutnya diharapkan menambahkan variabel yang lain yang kemungkinan dapat mempengaruhi kebijakan dividen, misalnya struktur modal, profitabilitas, pertumbuhan dan lainnya, sehingga model yang diperoleh akan lebih menjelaskan perilaku kebijakan dividen dalam setiap entitas di Indonesia.

\section{DAFTAR PUSTAKA}

Bhattacharya S. (1988). Corporate Finance and the Legacy of Miller and Modigliani. Journal of Economic Perspectives, 2(4), 135-147.

Brigham, F. dan Gordon, J. (1968). Leverage, Dividend Policy, and the Cost of Capital. Journal of Finance, 23, 85-103.

Chen, C. dan Steiner, J. (1999). Managerial Ownership and Agency Conflicts : a Nonlinear Simultaneous Equation Analysis of Managerial Ownership, Risk taking, Debt Policy, and Dividend Policy. Financial Review, 34, 119-136.

Crutchley, C. dan Hansen, R. (1989). A Test of the Agency Theory of Managerial Ownership, Corporate Leverage and Corporate Dividends. Financial Management, 18, 36-46.

Dempsey, S. dan Laber, G. (1992). Effects of Agency and Transaction Cost on Dividend Payout Ratios : Further Evidence of the Agency-Transaction Cost Hypothesis. Journal of Financial Research, 15, 317-321.

Duha, A. K. (2009). Determinants of the Dividend Policy in Emerging Stock Exchange: The Case of GCC Countries. Global Economy and Finance Journal, 3(2), 38-63.

Easterbrook, F. H. (1984). Two Agency Cost Explanation of Dividends. American Economic Review, 74(4), 650-659.

Ghozali, Imam. (2009). Aplikasi Analisis Multivariate dengan Program SPSS. Semarang: Badan Penerbit Universitas Diponegoro.

Harada, K. dan Nguyen, P. (2011). Ownership concentration and dividend policy in Japan. Managerial Finance, 37(4), 362 - 379. 
Hu, A. dan Kumar, P. (2004). Managerial Entrenchment and Payout Policy. Journal of Financial and Quantitative Analysis, 39(4), 759-790.

Jensen, M. dan Meckling, W. (1976). Theory of the Firm: Managerial Behavior Agency Cost, and Ownership Structure. Journal of Finance Economics, 3, 305-360.

Mancinelli, L dan Ozkan, A. (2006). Ownership structure and dividend policy : Evidence from Italian Firms. The European Journal of Finance, 12, 265-282.

Miller, M. H., dan Modigliani, F. (1961). Dividend Policy, Growth, and the Valuation of Shares. Journal of Business, 34(4), 411-433.

Miller, M. H., dan Modigliani, F. (1966). Some Estimates of the Cost of Capital to the Utility Industry. American Economic Review, 56, 333-391.

Miller, M. H., dan Rock, K. (1985). Dividend Policy under Asymmetric Information. Journal of Finance, 40, 1031-1051.

Mohd, M., Perry, L., dan Rimbey, J., (1995). An Investigation of Dynamic Relationship Between Agency Theory and Dividend Policy. The Financial Review, 30, 367-385.

Rozeff, M. S. (1982). Growth, Beta and Agency Costs as Determinants of Dividend Payout Ratios. The Journal of Financial Financial Research, 5, 249-259.

Shleifer, A. dan Vishny, R.W. (1986). Large Shareholders and Corporate Control. The Journal of Political Economy, 94(3), 461-488.

Shleifer, A. dan Vishny, R.W. (1997). A Survey of Corporate Governance. The Journal of Finance, 52(2), 737-783. 